TEME, г. XLIV, бр. 1, јануар - март 2020, стр. 139-157

\begin{tabular}{lr}
\hline Оригинални научни рад & https://doi.org/10.22190/TEME180402013J \\
Примљено: 2. 4. 2018. & UDK 342.72-055.3(497.11)
\end{tabular}

Ревидирана верзија: 24. 1. 2020.

Одобрено за штампу: 20. 2. 2020.

\title{
ЛГБТ ОСОБЕ У СРБИЈИ: ИЗМЕБУ ФОРМАЛНОГ ПРИХВАТАЊА И НЕФОРМАЛНОГ ОДБАЦИВАњА
}

\author{
Милош Јовановић \\ Универзитет у Нишу, Филозофски факултет, Департман за социологију, \\ Ниш, Србија \\ milos.jovanovic@filfak.ni.ac.rs
}

\begin{abstract}
Апстракт
Европеизација се, уопштено, дефинише као „процес у којем државе усвајају правила ЕУ”. Док се Србија приближава Европској унији, овај процес постаје све интензивнији, али се не одвија без проблема и застоја. Формални напори усмерени на промену друштвеног статуса ЛГБТ особа у Србији представљају пример описаног процеса, јер су повезани са идејом европеизације. У складу са условима ЕУ, усвојени су бројни закони усмерени на борбу против дискриминације ЛГБТ особа, реализовани су програми са истим циљем, а уз то је одржано неколико Парада поноса без већих инцидената (будући да је Београд био „под опсадом” јаких полицијских снага). Истовремено, високи државни званичници јавно показују отклон према нехетеросексуалним особама, а полиција пружа индиректни отпор организовању Прајда.

Државне акције које афирмишу ЛГБТ популацију карактерише краткотрајност и површност, што чини овај случај парадигматичним кад је у питању став Владе Србије према европеизацији: испуњавају се формалне обавезе (као наметнуте), а истовремено се предузимају велики (неформални) напори да у друштву не дође до промена. Циљ овог рада је да се демонстрира наведено.

Чини се да покушаји дифузије правила и прописа ЕУ не могу да рачунају на успех без локалног прилагођавања, те без узимања у обзир тумачења, прихватања и отпора које ове норме изазивају.
\end{abstract}

Кључне речи: ЛГБТ, Србија, европеизација, формална правила, неформалне праксе.

\footnotetext{
${ }^{a}$ Рад је наставо у оквиру пројекта Closing the Gap Between Formal and Informal Institutions in the Balkans (INFORM), који је финансиран из програма Европске уније за истраживања и иновације HORIZON 2020, у складу са споразумом о додели средстава № 6935237.
} 


\title{
LGBT PERSONS IN SERBIA: BETWEEN FORMAL ACCEPTANCE AND INFORMAL REJECTION
}

\begin{abstract}
Generally speaking, Europeanization is defined as "a process in which states adopt EU rules". As Serbia is getting closer to the EU, this process is gaining on the momentum, but running far from smoothly. Formal endeavors aimed at the change of the social status of the LGBT persons in Serbia are a case in point, as they are linked to the idea of Europeanization. In accordance with the EU conditions, a number of laws aimed at fighting discrimination of LGBTs were passed, programs with the same goal were implemented, and several Pride Parades took place without major incidents (as Belgrade was "besieged" by heavy police forces). At the same time, high state officials publicly manifest their reluctance toward non-heterosexuals, with the police practicing indirect resistance toward organizing the Pride.

The LGBT affirming actions were characterized by short time-span and superficiality, and this is what makes this case a paradigmatic one of the Serbian Government's attitude to Europeanization: the formal obligations (as imposed) are fulfilled, while simultaneously enormous (informal) efforts are undertaken in order that no changes occur in society. The goal of this paper is to demonstrate the aforementioned. Attempts to diffuse EU rules and regulations seem to be of no avail if local adaptation, interpretation and appropriation of these norms and resistance which they spawn, is not taken into account.
\end{abstract}

Key words: $\quad$ LGBT, Serbia, Europeanization, Formal norms, Informal practices.

\section{УВОД: КОНТЕКСТ ЕВРОПЕИЗАЦИЈЕ}

У последњих неколико година, у Србији је спроведен низ мера у циљу побољшања друштвеног положаја ЛГБТ ${ }^{1}$ особа: усвојен је низ закона који су садржали одредбе усмерене на борбу против дискриминације нехетеросексуалних особа, спроведени су програми и састављени акциони планови са истим циљем, а уз то је одржано неколико „Парада поноса” без већих инцидената. Непосредни и интензивни подстрек за овакво деловање дошао је из Европске уније (у контексту борбе против свих облика дискриминације), којој, у смислу постајања чланицом, Србија тежи - што је изричито потврђено као стратешко опредељење доношењем Резолучије о придруживању

\footnotetext{
${ }^{1}$ У овом раду ће за означавање особа нехетеросексуалне оријентације и/или неконвенционалног родног идентитета бити коришћена скраћеница ЛГБТ - из практичних разлога, будући да је већ прихваћена у јавном дискурсу, у коме је, треба напоменути, заступљеност лезбијки и гејева много већа у односу на бисексуалне и транс особе. Иначе, постоје и дуже варијанте акронима, попут: LGBTTIQ - лезбијке, гејеви, бисексуалне, трансродне, трансексуалне, интерсексуалне и квир особе (в. Јарић, 2011; Радоман, 2017), или: LGBTTIA2SQQ - лезбијке, геј, бисексуалне, транссексуалне, трансродне, интерсекс, асексуалне, $2 \mathrm{~S}$ (људи са „две душе”, енгл. two-spirited), квир (енгл. queer) и особе које испитују своје опредељење (енгл. questioning) - (Група организација, 2015).
} 
Европској унији у Народној скупштини Републике Србије још октобра 2004. године ${ }^{2}$.

Могло би да се каже да је европеизација - „процес кроз који државе усвајају правила ЕУ" (Schimmelfennig \& Sedelmeier, 2005, 7) - Србије формално отпочела преговорима Европске уније и Србије и Црне Горе о закључењу „Споразума о стабилизацији и придруживању” октобра 2005. године. Иначе, Радели даје нешто сложенију дефиницију европеизације када пише да је чине

\begin{abstract}
процеси а) изградње, б) дифузије и в) институционализације формалних и неформалних правила, процедура, парадигми јавних политика, стилова, „начина како се ствари раде” и заједничких уверења и норми који су најпре дефинисани и утврђени у ЕУ кроз стварање јавних политика и затим уграђени у логику домаћег (државног и регионалног) дискурса, политичких структура и јавних политика (Radaelli, 2004, 3).
\end{abstract}

Пут Србије ка Европи био је и, по свему судећи, остаје пун препрека и заобилазница, застоја, али и узмицања (видети у: Subotić, 2010). То не чуди ако се узму у обзир: (релативна) скорашњост оружаних конфликата и нерешено питање територијалног суверенитета и интегритета, привредни колапс (без јасног смера економског опоравка на видику), слаба владавина права и одсуство независног судства, државна контрола медија (Subotić, 2017). Ушанчени политички систем неопатримонијализма - феномен „заробљавања државе” (state capture; Pešić, 2007) и велики број овим изазваних проблема отежава преображај и демократизацију друштвеног живота у Србији и његово довођење у склад са принципима Европске уније „спољни подстицаји не дају резултат када држава нема капацитета за спровођење своје политике и не контролише све структуре потребне за то" (Stojanović, 2013, 69).

Као политички услов за приступање Унији наводи се да држава кандидат мора да има „стабилне институције које гарантују демократију, владавину права, људска права и поштовање и заштиту

\footnotetext{
${ }^{2}$ Србија је направила први корак ка европским интеграцијама 8. октобра 2000. године, када се тадашња Савезна Република Југославија прикључила „Процесу стабилизације и придруживања”. За кратак историјат односа Србије и ЕУ видети страницу Министарства за европске интеграције Владе Србије: http://www.mei.gov. rs/src/srbija-i-eu/istorijat-odnosa-srbije-i-eu/.
} 
мањина"3. Као један сегмент тог захтева појављује се однос државе према сексуалним мањинама ${ }^{4}$.

Циљ овог рада је да се демонстрира теза да је случај односа Србије према ЛГБТ популацији парадигматичан за општији процес европеизације ове земље: формалне обавезе се испуњавају, али без већих напора да се изазову значајније друштвене промене - усвајање правила не достиже „супстантивни ниво”, већ остаје на „вербалном” и формално „легалном” (в. Elbasani, 2013, 14). Акције представљене као позитивно усмерене ка ЛГБТ особама су краткотрајне и површне. Оспоравања и опирања државних органа и службеника нема на нивоу званичног дискурса, већ на нивоу праксе (Ejdus \& Božović, 2016), тако да формални подухвати остају „празне љуштуре” са мало или без икаквог стварног друштвеног утицаја (Dimitrova, 2010). „Што је слабији положај државе (statehood) у земљи, то је већа вероватноћа да ћемо пронаћи несклад између формалних преноса и преовлађујућих неформалних пракси и институција, што као последицу има површну европеизацију" (Elbasani, 2013, 18), уз све веће продубљивање јаза између формалних правила и неформалних пракси (в. Mungiu-Pippidi, 2014, 28).

Овај рад се при анализи отклона од ЛГБТ популације неће бавити „евроскептицима”, „противницима идеологије “хомосексуализма' наметнуте са Запада", нити другим традиционалистичким, националистичким или клерикалним борцима против равноправног третмана нехетеросексуалаца у Србији. Биће разматране ненамераване и амбивалентне, чак негативне, последице које има прихватање императива $\mathrm{EV}^{5}$ само привидно (а не суштински), уз покушај идентификовања корективних стратегија које би водиле ка равноправном статуса ЛГБТ особа, и то управо према европским критеријумима.

\footnotetext{
${ }^{3}$ Овај критеријум дефинисао је Европски савет у Копенхагену 1993. године и он се редовно наводи као први, пре економског (функционисање тржишне привреде) и административног (постојање институционалних капацитета за примену одредби правне тековине ЕУ - acquis communautaire).

4 „Европска комисија је у писаној напомени навела да је поштовање права хомосексуалаца правни критеријум за приступање ЕУ. Навела је тзв. Копенхагенске критеријуме о подобности за придруживање из 1993. године и члан 2 Споразума o функиионисању $E У$, којим се забрањује дискриминација 'мањина'. Такође је навела чланове 10 и 19 Споразума о функиионисању EУ и члан 21 Повеље Европске уније о основним правима, који изричито забрањују дискриминацију на основу 'сексуалне оријентације'. 'Права ЛГБТ особа (лезбијки, гејева, бисексуалних и трансродних особа) чине саставни део и Копенхагенских политичких критеријума за приступање и правног оквира ЕУ у борби против дискриминације. Европска комисија пажљиво надгледа њихово спровођење и годишње извештава о напретку земаља кандидата у вези са ситуацијом ЛГБТ заједнице" (Rettman, 2012; видети и: Ayoub, 2016, 9).

5 „Земље кандидати немају гласа током стварања правила која регулишу њихов напредак у процесу придруживања" (Elbasani, 2013, 8).
} 


\section{ФОРМАЛНЕ ПРОМЕНЕ У ОДНОСУ ПРЕМА ЛГБТ ПОПУЛАЦИЈИ}

Србија је декриминализовала хомосексуалност 1994. године брисањем члана 110 из тадашњег Кривичног закона, а касније је донела низ закона који садрже изричиту забрану дискриминације на основу сексуалне оријентације.

Најпре, Закон о радиодифузији из 2002, у коме се санкционише ширење информација које подстичу дискриминацију, мржњу и насиље, између осталог и на основу сексуалне оријентације. Ова одредба је касније унета у Закон о јавном информисању и медијима који је донет 2014. године.

Закон о високом образовағу и Закон о раду, донети 2005, такође изричито помињу сексуалну оријентацију у контексту забране дискриминације, што је случај и са Законом о младима и Законом о сочијалној заштити из 2011, Законом о електронским медијима из 2014. и Законом о огламавању из 2016. године (с тим што се у последњем наводи „сексуално опредељење” уместо „оријентације”б).

Усвајању Закона о забрани дискриминащије 2009. године претходио је низ покушаја његове измене или потпуног стопирања, управо због одредаба које се односе на сексуалну оријентацију и родни идентитет - део члана 21 из предлога закона, који се односи на родни идентитет, уклоњен је (в. Jovanović, 2013, 89-91). Између осталог, овим Законом установљена је функција Повереника за заштиту равноправности као самосталног државног органа 7.

Закон о здравственом осигурању, донет 2011. године, предвиђа да држава сноси најмање $65 \%$ од цене здравствене услуге из средстава обавезног здравственог осигурања код операција промене пола из медицинских разлога (члан 45). Закон о поличији из 2016. године забрањује дискриминацију на основу пола, рода и родног идентитета, што представља „напредак у односу и поступању државних органа према трансродним и трансполним особама као вишеструко осетљивој категорији становништва изложеној честим кршењем њихових права" (Јовановић, 2017, 11). У Закону се експлицитно не помиње забрана дискриминације на основу сексуалне оријентације, с тим што у члану 27 стоји да полиција развија „професионалне капацитете и компетенције и етику полицијских службеника за друштве-

\footnotetext{
${ }^{6}$ Осећање сексуалне привлачности није ствар слободног нахођења, избора или рационално донете одлуке, те је због тога уместо „сексуалног опредељења" исправније користити синтагму „сексуална оријентација”.

${ }^{7}$ Сви случајеви дискриминације на основу сексуалне оријентације који су пријављени овом органу, заједно са мишљењем и препорукама, могу се наћи на вебстраници www.ravnopravnost.gov.rs/rs/сексуална-оријентација.
} 
но одговорно деловање полицијске службе уз пуно поштовање људских и мањинских права и слобода и заштиту свих рањивих група", што би имплицитно могло да се односи на ЛГБТ особе. Такође, у члану 33 Закона, као утврђени и достигнути стандард полицијског поступања наводи се „остваривање људских и мањинских права и слобода”, те „недискриминациј[а] при извршавању полицијских задатака".

Са изменама Кривичног законика 2012. године, уведена је одредба (54а) којом се сексуална оријентација и родни идентитет наводе као отежавајуће околности за одмеравање казне за „злочин из мржње".

Када је у питању однос према нехетеросексуалцима, држава Србија је на пољу јавних политика била видно активна. Јуна 2013. године Влада је усвојила Стратегију превениије и заштите од дискриминачије, а оквир за спровођење стратешких циљева прецизиран је кроз Акииони план за примену Стратегије превенције и заштите од дискриминаиије за период од 2014. до 2018. године 9 . Основни циљ Стратегије је поштовање уставног начела забране дискриминације осетљивих друштвених група, међу којима су препознате и ЛГБТ особе, на које се односе Општи циљеви, који се првенствено, али не искључиво, тичу формалне (законске) сфере:

Усклађивање правног оквира са међународним стандардима. Спречавање кршења забране дискриминације према ЛГБТ особама, кроз уставне, законодавне, регулаторне реформе као и доношење стратешких документа. Укидање или смањење дискриминаторских пракси према ЛГБТ особама у различитим областима. Обезбеђење услова за спровођења Закона о забрани дискриминације у делу који се односи на дискриминацију ЛГБТ особа. Промена јавних политика у одређеним областима које могу да буду извор дискриминације ЛГБТ особа. Институционална заштита ЛГБТ особа од јавног и приватног насиља, нарочито у области рада и запошљавања, здравственог и социјалног система, личног и породичног живота, образовања, спорта и др. Промена традиционалног, негативног стереотипа о ЛГБТ особама. Спречавање и кажњавање говора мржње и физичких напада на ЛГБТ особе. Унапређивање статуса и положаја ЛГБТ особа. (Одељак 4.4.3. Cmpameгије). ${ }^{10}$

\footnotetext{
${ }^{8}$ Шире о нормативном оквиру у Србији у области ЛГБТ права видети: Јовановић, 2017.

${ }^{9}$ Оба документа су доступна на сајту Канцеларије за људска и мањинска права Владе Србије: http://www.ljudskaprava.gov.rs/sr/node/145 (последња посета: 8. 3. 2018).

${ }^{10}$ Стратегија предвиђа и мере за остваривање Општих циљева (Одељак 4.4.4), а Одељци 4.4.5.1 - 4.4.5.7. садрже Посебне циљеве из седам области: 1) Слобода мирног окупљања, слобода изражавања и политичка и друштвена партиципаци-
} 
Министарство унутрашњих послова је фебруара 2014. године донело Акииони план за унапређење рада и сарадње полииије са ЛГБТ популачијом, који предвиђа борбу против хулиганизма и екстремизма, опредељивање официра за везу и реализацију пројеката са циљем поштовања различитости.

Уз подршку Владе Србије и Савета Европе, спроведен је програм Унапређење система соиијалне заштите за ЛГБТ особе и ғихове породище ${ }^{11}$, а Влада је финансирала и пројекат Стварање толераниије и разумевања према ЛГБТ популачији у српском друштву ${ }^{12}$.

Јуна 2017. године, Ана Брнабић, која је истополно сексуално оријентисана, именована је за премијерку. Ово је свакако чин који је повећао видљивост лезбијске популације у Србији. Посебно је занимљиво да је Брнабић подршку добила и од представника Српске православне цркве ${ }^{13}$, која иначе има неблагонаклон став према „промоцији хомосексуализма" (в. Jovanović, 2013).

Поред свега наведеног, у Србији је „успешно” одржано и више Парада поноса (в. Графикон 1), и то не само у Београду већ и у Нишу и Новом Саду. Престоница већ две године заредом има две Параде (јунску и септембарску). Ова дешавања, као и пратеће јавне дебате и оспоравања, добили су велики медијски публицитет и недвосмислено допринели већој видљивости ЛГБТ популације, што, према Филипу Ајубу (Ayoub, 2016), као крајњи ефекат има побољшање њеног положаја.

ја ЛГБТ особа, 2) приватни и породични живот, 3) рад и запошљавање, 4) образовање, 5) здравље и здравствена заштита, 6) социјална заштита, и 7) спорт, становање и укрштена дискриминација (в. Јовановић, 2017, 35-37).

${ }^{11}$ Више о пројекту: http://www.asocijacijaduga.org.rs/wp-content/uploads/2016/08/ brosura-text-grafosel.pdf (последња посета: 8. 3. 2018).

${ }^{12}$ Више о програму: http://www.ljudskaprava.gov.rs/sh/node/19809 (последња посета: 8. 3. 2018).

13 „Ана Брнабић добила је пуну подршку врха СПЦ за премијерску функцију (...) епископ загребачко-љубљански Порфирије (Перић), који је у Скупштину Србије дошао заједно са патријархом српским Иринејом, пришао је министраки Брнабић чим ју је угледао у маси, љубазно се поздравио са њом, а онда јој пренео поруку СПЦ. Владика Порфирије, који је сада и члан Синода СПЦ (...), пришао је министарки, ухватио је за обе руке и дословно јој рекао: 'Ево и уживо да вам кажем, имате моју и пуну подршку Цркве да будете премијер, о вама мислимо све најбоље. Нико се томе не противи, заиста. Молим вас, немојте да верујете свакојаким гласинама" (http://www.alo.rs/otkrivamo-spc-zelimo-da-ananasledi-vucica/109503, последња посета: 15. 3. 2018). 


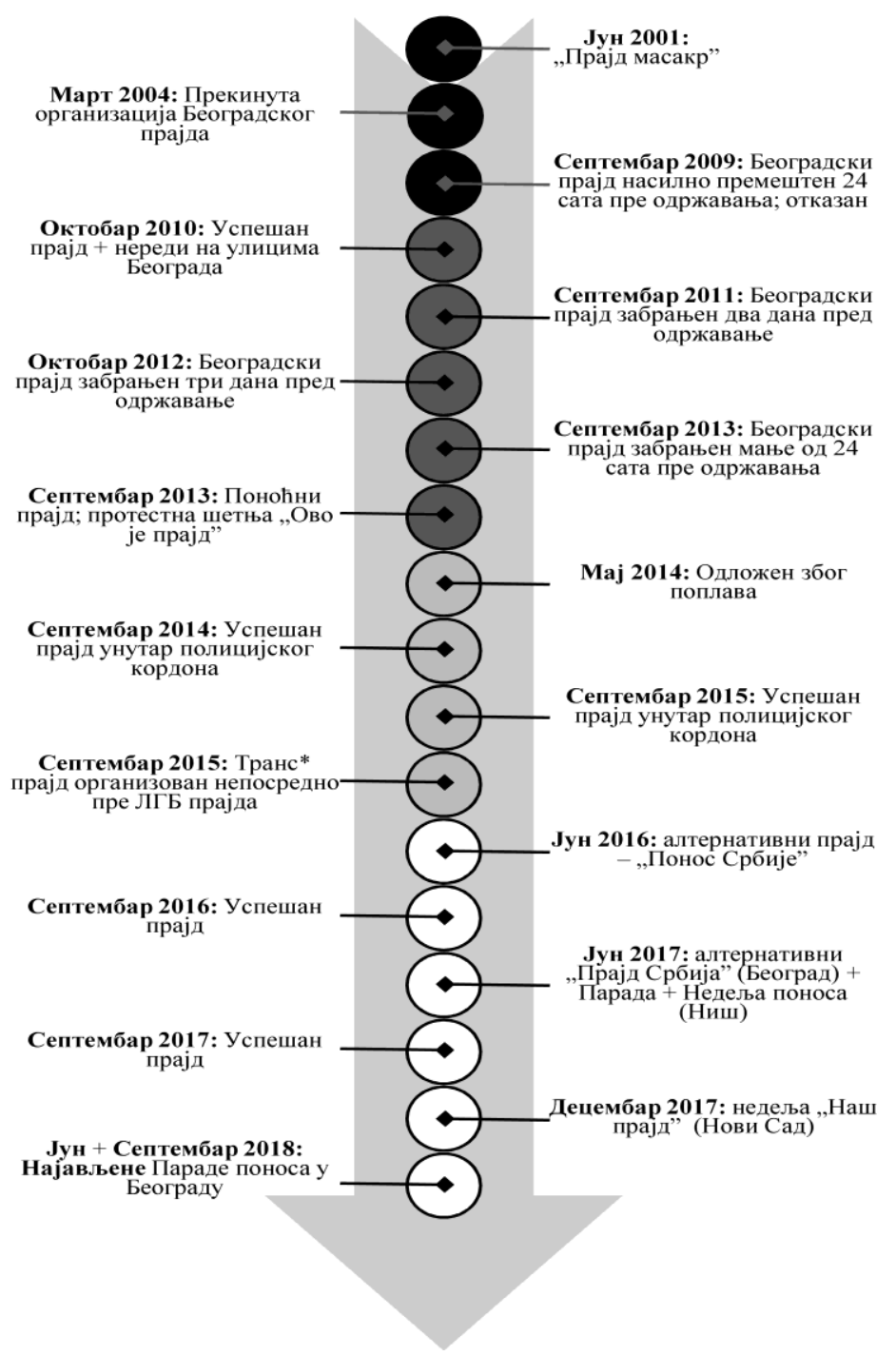

Графикон 1: Историјски преглед Прајда (Парада поноса) у Србији између 2001. и 2018. године

Фаза $1 \bullet$ Парада: од насиља до забране

Фаза $2 \bullet$ Од „државног прајда” до претње по јавну безбедност

Фаза $3 \bullet$ Парада као хомонационалистички потез

Фаза 4 ○ Парада без инцидената, алтернативни прајд и параде/недеље поноса ван Београда

\footnotetext{
${ }^{14}$ Графикон представља модификацију Figure 1 (Slootmaeckers, 2017a, 521). До-
} дати су подаци за период 2016-2018. и Фаза 4. 
Горенаведене мере и догађаји имали су извесног утицаја на промену става грађана Србије према хомосексуалцима, но он је и даље код преовлађујућег дела становништва остао обележен нетрпељивошћу и осудом ${ }^{15}$.

О помаку према прихватању нехетеросексуалаца у Србији сведоче и подаци из истраживања спроведеног 2017. године у оквиру пројекта Closing the Gap Between Formal and Informal Institutions in the Balkans (INFORM) ${ }^{16}$. Када се одговори на питање о „оправданости хомосексуалности" упореде са подацима из Европског истраживањ а вредности (European Values Study - EVS) ${ }^{17}$ из 2008. и Aнкете о вредностила у свету (World Values Survey) ${ }^{18}$ из 2001. године, може се уочити повећање заступљености позитивног става међу становницима Србије из 2017.

Табела 1. „Молим вас, рещите ми да ли су, према Вамем мишљењу, следећи обличи понашања увек оправдани, никад нису оправдани или нешто између - хомосексуалност." (скала 1-10; 1 = никад, 10 = увек)

\begin{tabular}{lccc}
\hline & $\begin{array}{c}\text { Хомосексуалност } \\
\text { оправадана } \\
\text { (одговори 6-10) }\end{array}$ & $\begin{array}{c}\text { Хомосексуалност } \\
\text { неоправдана } \\
\text { (одговори 1-5) }\end{array}$ & $\begin{array}{c}\text { mean / std. } \\
\text { dev. }\end{array}$ \\
\hline WVS 2001 & $\mathbf{5 , 4 \%}$ & $\mathbf{8 6 , 8} \%$ & $1,96 / 1,98$ \\
EVS 2008 & $\mathbf{5 , 9 6 \%}$ & $\mathbf{9 4 \%}$ & $1,82 / 1,90$ \\
INFORM 2017 & $\mathbf{1 3 , 2} \%$ & $\mathbf{7 9 , 4 \%}$ & $2,74 / 2,58$ \\
\hline
\end{tabular}

Узевши у обзир промене у сфери законских норми ${ }^{19}$, усвојене државне стратегије, чињеницу да је лезбијка на месту премијера и Параде одржане без инцидената, не може се рећи да је у Србији

\footnotetext{
${ }^{15}$ Више о доминантном ставу према хомосексуалцима у Србији видети: Јовановић, 2016, 55-72; 84-86.

${ }^{16}$ Истраживање је реализовано на репрезентативном узорку 1127 грађанки и грађана Србије старијих од 18 година. Прикупљање података обављено је у периоду мај-јун 2017. године.

${ }^{17}$ База са подацима доступна је на сајту: http://www.europeanvaluesstudy.eu/page/ survey-2008.html. Информације о узорку (1512 испитаника и испитаница) и прикупљању података у Србији доступни су на страници: https://infol.gesis.org/ EVS/Studies/.

${ }^{18}$ Подаци (за 1200 испитаника и испитаница из Србије) доступни су за онлајн анализу на сајту: http://www.worldvaluessurvey.org.

${ }^{19}$ Антидискриминационо законодавство не представља стандард у ЕУ, тако да има „напреднијих” земаља (нпр. Пољска), које још увек немају законе који постоје у Србији (примедба уредника у: Blagojević, 2011, 28, n2).
} 
постигнуто мало. ${ }^{20}$ Према речима дугогодишњег активисте који коментарише садашњу ситуацију у односу на ону из времена СФРЈ:

Успели смо да ставимо (ЛГБТ) питање на сто и на јавном и на политичком нивоу; то је сада опште место (mainstream). Hе бих рекао да је популарно или претерано позитивно, али бар је ту. Сада нико не може да игнорише ово питање, што је за мене израз највеће хомофобије (Swimelar, 2017, 931-2; из интервјуа вођеног новембра 2014. у Београду).

Ипак, све од горенаведених мера имају и проблематичну страну - како у смислу њиховог утицаја на свакодневни живот нехетеросексуалних и родно неконвенционалних људи тако и на карактер и последице ЛГБТ афирмативног политичког деловања у Србији. У наредном одељку се окрећемо овим проблематичним последицама.

\section{НЕНАМЕРАВАНИ И АМБИВАЛЕНТНИ ЕФЕКТИ}

Као што је хомосексуалност у Србији 1994. декриминализована „одозго”, као део једне од рутинских правних реформи, без претходних иницијатива самих грађана и јавне расправе, тако су и горенаведени закони такође стигли „одозго”, овога пута као производ притисака Европске уније (Kahlina, 2015, 77-78), кроз „педагогију условљавања" (levered pedagogy; Kulpa, 2014) - хегемонски дидактички однос где се Централна и Источна Европа појављују као предмет Западноевропске „педагогије” и представљају као трајно „посткомунистичке”, „У транзицији” (,још увек недовољно либералне”) и хомофобичне, уз прећутну претпоставку о универзалности западноевропског либералног модела.

Закони су, од стране државе, инструментализовани у процесу европских интеграција, а нису донети као аутентични „правни инструмент за заштиту “мањина”' (Bilić, 2016a, 130) - нису били резултат grassroots акција „одоздо 21 . Уз то, послужили су као још једна од инстанци дистанцирања од Милошевићевог режима 22.

Такође проблематично у вези са нормативно-прескриптивним оквиром јесте питање одговарајуће примене закона у пракси (Зекавица, 2016, 355; в. Mendelski, 2016, 355), те квалитета и усклађености закона и других правних аката (Николић, 2012, 141).

\footnotetext{
${ }^{20}$ Институција грађанске истополне заједнице и признавања наследних права истополних партнера и партнерки једно је од питања које чека на регулисање.

${ }^{21}$ Међутим, ово је проблем који се тиче законодавства уопште у Србији, а не само правних аката усмерених на регулисање статуса мањина.

${ }^{22}$ У Хрватској је, слично, процес придруживања делом био дистанцирање од Југославије кроз дискурс „повратка у Европу” (Kahlina, 2015, 78).
} 
Посебно је индикативно да члан Кривичног законика који се односи на злочин из мржње у Србији ,још ниједном није примењен ни по једном Законом предвиђеном основу, а не само по основу сексуалне оријентације или родног идентитета" (Зекавица, 2016, 356; видети и: Исаковић и Жолт, 2016, $401 \mathrm{n} 6, \mathrm{n} 7)$. Имплементација Закона о забрани дискриминаиије, осам година након ступања на снагу, остаје минимална (Slootmaeckers, 2017b). Одсуство адекватне примене и неефикасност судства када су у питању напади на ЛГБТ особе стварају јавни простор који одликује „култура некажњивости” (Stakić, 2011, 60; за податке о насиљу видети: Ковачевић, $2018^{23}$ ), што може само да подстакне насилно понашање, уместо да га спречи.

„Преношење” формалних правила ЕУ не мора нужно да прати стварно „довођење у ред” одређене области. Има аутора које посебно забрињава империјалистичка пракса ЕУ, која се делом спроводи кроз формално-легалистички дискурс људских права, уз занемаривање локалног социјалног контекста:

[3]акон - без значајних промена у српском друштву и политичкој култури - заправо не чини ништа друго осим што ојачава инфантилно провинцијално стање духа, које је опет (кроз саму „стратегију инклузије”) искључиво не само у односу на маргинализоване појединце и групе, већ и у односу на тражење алтернатива и политичких могућности (Blagojević, 2011, 38; видети и: Ammaturo, 2017).

Правни акти којима се штите људска права, без постојања развијене демократске културе и политичког плурализма, који подразумева довољно снажне политичке опције које би биле супротстављене доминантном неолибералном дискурсу, остају не више од „слова на папиру”.

Некритички преносећи Западно искуство ${ }^{24}$ (означено као „напредно” и „модерно”), као главни проблем поставља се питање права на јавно окупљање и изражавање, што одржавање Парада поноса претвара у мерило (,лакмус тест" - Slootmaeckers, 2017a) степена европеизованости „заостале” и „хомофобичне” земље. Опис Параде одржане 2010. године сведочи о наведеном:

\footnotetext{
${ }^{23}$ Требало би напоменути да је било јавних реакција на овде наведен извештај о насиљу над ЛГБТ особама, где се он критикује и износе тврдње о знатно већој распрострањености насиља над нехетеросексуалном и родно неконвенционалном популацијом (видети: http://rs.n1 info.com/Vesti/a390244/Centar-Vise-nasiljanad-LGBT-osobama-nego-u-izvestaju.html; последња посета: 29. 11. 2018).

${ }^{24}$ При чему не треба заборавити да „Србија није имала ни приближно сличан историјски ток геј-лезбејског активизма оном у САД-у или неким европским земљама" (Маљковић, 2014, 365). Више о друштвеном контексту и историји ЛГБТ активизма у Србији видети: Bilić, 2016b, 206-208.
} 
Иконографија и језик који су коришћени на самој Паради су били Западни или глобални, што је само долило уље на ватру критици Параде као нечег страног и увезеног. У маси је могла да се види застава ЕУ, заједно са заставама дугиних боја и љубичастом заставом Велике Британије, али не и српска застава. Музика у позадини била је Западни поп. Ако су говорници (углавном странци) помињали Србију, обично је то било у негативном контексту, као место где не владају европске норме људских права. Занемарљиви су били покушаји да се призову неке од локалних традиција разноликости и толеранције (Mikuš, 2015, 22).

Будући део дискурса цивилног друштва, Парада је преузела глобалну и западну иконографију. Овај грађански дискурс је због тога обележен као „стран”, „увезен” и „наметнут”. У том контексту је врло занимљива и политички ефикасна интервенција дрег-краљице у српској народној ношњи на септембарском Прајду 2018. године у Београду, која изјављује: „Љубав је оно што је традиционална вредност, а не насиље и мржња - то желим да поручим својим аутфитом",25.

Српска политичка елита, кроз тактичко европеизирање („чин повиновања који ЕУ треба да пренесе спремност на европеизирање кроз усаглашавање са одређеним 'европским нормама'”, Slootmaeckers, 2017b), спроводи апропријацију и експлоатацију Параде („државни прајд”, Mikuš, 2011) тако демонстрирајући своју (наводну) оријентисаност ка Европи, без праве заинтересованости за ЛГБТ питања, што потврђују хомофобне изјаве водећих политичара ${ }^{26}$, које су такође и вид додворавања њиховој конзервативној изборној бази.

„Државни прајд” је 2014, кроз милитаризацију ${ }^{27}$ (Ejdus \& Božović, 2016), претворен у „Параду авети” (Ghost pride) - учесници ритуалне шетње кроз полицијски обезбеђену сигурну зону остали су

${ }^{25}$ http://lolamagazin.com/2018/09/25/sta-ce-zena-sama-u-kafani-sta-ce-dreg-kraljicasama-u-srpskoj-nosnji/; последња посета: 29. 11. 2018.

${ }^{26}$ На пример, изјава Ивице Дачића из септембра 2012: „Изем ти такву Унију у коју је геј парада улазница" (https:/www.blic.rs/vesti/politika/dacic-izem-ti-takvuuniju-u-koju-je-gej-parada-ulaznica/q710bq5; последња посета: 29. 3. 2018), или одговор Александра Вучића на позив да буде на челу Параде 2017: „Немам намеру да идем. Нисам неко ко је одушевљен таквом манифестацијом. Без обзира на то, моја обавеза је, и то сам успео да остварим, да се њима гарантује право да чине оно што је део њихове слободе и њихових права и због тога сам задовољан. (...) Не пада ми на памет. И то је моје право да одбијем, да шетам где хоћу и кад хоћу. Хвала на позиву. Heћy.” (https://www.blic.rs/vesti/drustvo/ organizatori-parade-ponosa-pozvali-vucica-da-stane-na-celo-kolone-vucic-hvalana/p878b4y; последња посета: 29. 3. 2018).

27 Занимљиво је да се полиција тада није отворено (формално) противила Паради (док полицијски синдикати јесу), већ је посредно (неформално) отежавала њено одржавање кроз низ техничких опструкција (Ejdus \& Božović, 2016, 10). 
невидљиви за ширу јавност, што је манифестацију лишило политичког садржаја, а тиме и могућих ефеката на друштво (Slootmaeckers, $2017 \mathrm{a}, 14)$. Готово да је у питању био „шоу” или „позоришна представа" за домаће и стране медије и изасланике ЕУ о томе колико је политичка елита (која је преузела „заслуге” за одржавање Параде ${ }^{28}$ ) посвећена европском пројекту борбе против дискриманације мањина, што је еклатантан пример формалне европеизације, без бављења суштинским питањима, као што су, на пример, конкретне мере за спречавање насиља које трпе ЛГБТ особе или ефикасно санкционисање говора мржње усмереног ка овој популацији.

Пошто је држава у великој мери присвојила Параду, ова је изгубила своју везу са ЛГБТ заједницом, ${ }^{29}$ на шта упућују резултати истраживања њених припадника из $2014 .{ }^{30}$ на питање „Да ли сте за одржавање Параде поноса у Србији?", најчешће дат одговор (38\%) јесте „Да, али не у овом облику каква је данас” (Стојаковић, 2014, 75). Занимљиво је да је у централној Србији, која обухвата сиромашније, национално хомогене и традиционалније крајеве, најчешћи одговор „Не”, за који се опредељује 51\% испитаника (76) - за њих је повећање видљивости ЛГБТ популације (што је и намера Параде) значило повећање насиља над њима у локалном окружењу. На питање шта би требало да буду циљеви ЛГБТ организација, одговор који добија највеће неслагање (32\%) јесте управо „Одржавање Параде поноса” (56-57). Организатори Параде, на основу података добијених кроз фокусгрупне интервјуе са припадницима ЛГБТ популације, немају легитимитет кад је у питању представљање ЛГБТ заједнице (189).

Постављање лезбијке за премијера, такође, треба читати као део тактичке европеизације - потеза који пре свега треба да Европи покаже „напредност” Србије, а који неће битно (ако уопште) утицати

\footnotetext{
${ }^{28}$ Видети део горенаведене изјаве Александра Вучића: „... моја обавеза је, и то сам успео да остварим, да се њима гарантује право да чине оно што је део њихове слободе и њихових права и због тога сам задовољан”.

29 Значење синтагме „ЛГБТ заједница” је нејасно. Помињући „заједницу без заједништва”, Душан Маљковић пише да се наведена фраза често користи „као синоним за тзв. геј сцену, тј. геј јавност, која се манифестује у активизму, клабингу итд., а коју такође можемо приупитати да ли адекватно адресира акроним ЛГБТ: на пример, где су представници 'Б' популације у организацијама, какви су односи међу самим 'припадницима' - како друге категорије третирају нпр. транссексуалце - и где се та заједница уопште види као политички субјекат који показује некакав релевантан степен јединства?” (Маљковић, 2014, 366, n7).

${ }^{30}$ Пригодни узорак чинило је 402 испитаника (163 жене, 225 мушкараца и 14 који су се по питању родне припадности изјаснили као „други”), коришћен је електронски упитник, а подаци су прикупљени у периоду јануар-април 2014, уз одржавање четири фокус-групе (у Новом Саду, Нишу и две у Београду) (Стојаковић, 2014, 13-15).
} 
на промену живота нехетеросексуалаца или владајућих ставова према њима - „симболички политички чин остаје само то: симболички” (Slootmaeckers, 2017b). Ипак, и као такав није без значаја: Србија је једна од изузетно ретких земаља у којој је случај да је лезбијка на челу врховног органа извршне власти. Нема сумње да ће на дужи рок ова чињеница утицати на побољшање положаја нехетеросексуалаца у Србији, а можда и у земљама региона.

Одсуство истинске намере „хватања у коштац” са проблемима ЛГБТ популације манифестује се и кроз мањкавости уочене у анализи Акиионог плана за спровођење Стратегије превенције и заштите од дискриминаиије, које се односе на „недостатак доследних рокова за спровођење, као и неопходних ресурса за реализацију” (Јовановић, 2017, 37). Нереални рокови и нераспоређена буџетска средства за имплементацију Стратегију претварају само у списак лепих жеља, која је тако постављена на пут ка сигурном забораву.

\section{ЗАКЉУЧАК: ПРОТИВ ПАТОЛОГИЗАЦИЈЕ ЕВРОПЕИЗАЦИЈЕ}

Када Мартин Менделски пише о „патолошкој моћи ЕУ”, која подрива успостављање владавине права у земљама југоисточне Европе (Mendelski, 2016), наводи три основна проблема европеизације, од чега су два присутна у пољу политике побољшања положаја ЛГБТ особа:

1) Вредновање квантитета уместо квалитета - логика „што више, то боље”, када су у питању законски прописи, води до повећања дискрепанције између формалних правила и неформалних пракси (358); инсистирање на квантитету исхода, без увида у квалитет процеса који до њих доводе - чини цео подухват неефикасним и мањкавим.

2) Пристрасно оснаживање домаћих актера промене - демократске реформе се поверавају контроверзним политичарима, који их користе за учвршћивање своје ауторитарне власти и недемократско обрачунавање са политичким противницима (359), што крајње кориснике реформи оставља ускраћенима за њихове ефекте. Из овога не би требало извући закључак да друштвене реформе које се тичу побољшања статуса ЛГБТ особа не треба спроводити „одозго”, већ да оне, да би биле ефикасне, морају да буду део ширих друштвенополитичких промена које би за циљ имале управо борбу против ауторитарне власти, демократизовање друштвеног живота и лустрацију „контроверзних” политичара.

Без осветљавања и проблематизовања свакодневних животних недаћа са којима су суочени припадници ЛГБТ популације у Србији, које у главној мери карактерише присилна ћутња, искљученост и страх да се не буде откривен и подвргнут горем третману и/или насиљу (Јарић, 2011), не може да буде ни побољшања њиховог положаја. 
Највећи део акција које су експлицитно усмерене на еманципацију и правичан третман нехетеросексуалаца, а као своје (ненамераване) последице имају маскирање њиховог стварног статуса - своде се на спектакл и празна обећања.

Стратегије ЕУ које би „олово дискриминације требало да алхемијски претвор[е] у злато толеранције” (Маљковић, 2014, 366) нису довољне, јер циљ није само толеранција. Да ЛГБТ особе не би биле „монета за поткусуривање у политичким једначинама”, технике активиста, који би да избегну искоришћавање од стране државних структура, треба да се

редефинишу тако да се ослаби или пресече појмовна веза између хомосексуалности/нехетеросексуалности и Европе и сексуална разноликост утемељи у локалним друштвено-политичким праксама и историјским контекстима (Брковић, према: Bilić \& Stubbs, 2016, 240).

Платформа за активистичке праксе у овом правцу не би смела да се сведе на „формалистичку и одвећ прагматичну” „мантру” људских права (Bilić, 2016a, 145). Захтевала би узимање у обзир ширих неравнотежа моћи и трендова у сфери политике (Bilić \& Stubbs, 2016, 244), уз уважавање интерсекцијске природе угњетавања (Bilić, $2016 \mathrm{a}, 145)$ и стварање наратива који „одговара” домаћим нормама и традицији кроз уоквиравање страних правила у препознатљиве локалне дискурсе ${ }^{31}$ (Ayoub, 2016, 34), што би поспешило изградњу локалних иницијатива и (само)оснаживање „заједнице”, што је од велике важности за ЛГБТ популацију, посебно ону ван Београда и других урбаних центара.

\section{ЛИТЕРАТУРА}

Ammaturo, F. R. (2017). European Sexual Citizenship: Human Rights, Bodies and Identities. Cham: Palgrave MacMillan. DOI 10.1007/978-3-319-41974-9

Ayoub, P. M. (2016). When States Come Out: Europe's Sexual Minorities and the Politics of Visibility, New York: Cambridge University Press. DOI 10.1017/CBO9781316336045

Bilić, B. (2016a). "Europe Gays? Europeanisation and Pride Parades in Serbia", in: B. Bilić (ed.) LGBT Activism and Europeanisation in the Post-Yugoslav Space: On the Rainbow Way to Europe, London: Palgrave Macmillan, pp. 117-153. DOI 10.1057/978-1-137-57261-5_5

\footnotetext{
${ }^{31}$ Некадашње постојање „заклетих девица” - „вирџина” (жена које су постајале „мушкарци”) у јужној Србији или предање о „голом Рељи”, које се око Ускрса оживљава у Бујановцу (http://www.politika.rs/scc/clanak/24469/Голи-Реља-бујановачки-бренд; последња посета: 29. 11. 2018), могли би да буду искоришћени као основа за „превођење” глобалних норми у локални контекст.
} 
Bilić, B. (2016b). "Whose Pride? LGBT 'Community' and the Organization of Pride Parades in Serbia", in: K. Slootmaeckers, H. Touquet \& P. Vermeersch (eds.) The EU Enlargement and Gay Politics: The Impact of Eastern Enlargement on Rights, Activism and Prejudice, London: Palgrave Macmillan, pp. 203-220. DOI 10.1057/978-1-137-48093-4_9

Bilić, B. \& Stubbs P. (2016). "Beyond EUtopian Promises and Disillusions: A Conclusion”, in: B. Bilić (ed.) LGBT Activism and Europeanisation in the Post-Yugoslav Space: On the Rainbow Way to Europe, London: Palgrave Macmillan, pp. 231-248. DOI 10.1057/978-1-137-57261-5_9

Blagojević, J. (2011). "Between Walls: Provincialisms, Human Rights, Sexualities and Serbian Public Discourses on EU Integration", in: R. Kulpa \& J. Mizielińska (eds.) De-Centring Western Sexualities: Central and Eastern European, London: Ashgate, pp. 27-41.

Dimitrova, A. (2010). "The New Member States of the EU in the Aftermath of Enlargement: Do New European Rules Remain Empty Shells?”, Journal of European Public Policy 17(1): 137-148. DOI 10.1080/13501760903464929

Ejdus, F. \& Božović, M. (2016). "Europeanisation and indirect resistance: Serbian police and Pride Parades", The International Journal of Human Rights. DOI 10.1080/13642987.2016.1161212

Elbasani, A. (2013). "Europeanization travels to the Western Balkans: Enlargement strategy, domestic obstacles and diverging reforms", in: A. Elbasani (ed.) European Integration and Transformation in the Western Balkans: Europeanization or business as usual?, London; New York: Routledge, pp. 3-21.

Група организација. (2015). Платформа за јачање улоге организаџија изивилног друштва у ииљу ефикасније заштите права и побољшања квалитета живота грађана и грађанки другачије сексуалне оријентације и родног идентитета у Републици Србији. Доступно на интернет адреси: http://transserbia.org/images/2015/dokumenti/LGBT-Platforma.pdf (последња посета: 1. 2. 2018)

Исаковић, М. \& Жолт, Л. (2016). „Проблем дискриминације ЛГБТ популације у Србији" ("The problem of discrimination against the LGBT population in Serbia”), Годишъак Филозофског факултета у Новом Саду XLI(2): 397413. DOI 10.19090/gff.2016.2.397-413

Јарић, И. (2011). „Живот између насиља и супкултурног гета: ЛГБТТИQ особе и њихова свакодневица у Србији” (“Life Between Violence and Subcultural Ghetto: LGBTTIQ Persons and Their Everyday Life in Serbia”), Антропологија 11(2): 141-164.

Jovanović, M. (2013). "Silence or condemnation: The Orthodox Church on homosexuality in Serbia“, Družboslovne razprave 29(73): 79-95.

Јовановић, М. (2016). Идентитет, религиозност, сексуалност: проблем идентитета религиозних ЛГБТ особа у Србији (Identity, Religiosity, Sexuality: Identity Problem of Religious LGBT Persons in Serbia), Нови Сад: Mediterran publishing

Јовановић, Н. (2017). Анти-дискриминациони нормативни оквир у Србији у области ЛГБТ права (Anti-Discriminatory Normative Framework in Serbia in the Field of LGBT rights), Београд: Лабрис - организација за лезбејска људска права. Доступно на интернет адреси: http://www.labris.org.rs/sites/ default/files/2 SR.pdf (последња посета: 1. 2. 2018)

Kahlina, K. (2015). "Local histories, European LGBT designs: Sexual citizenship, nationalism, and 'Europeanisation' in post-Yugoslav Croatian and Serbia", Women's Studies International Forum 49: 73-83. DOI 10.1016/j.wsif.2014. 07.006 
Ковачевић, М. (2018) Подаци, а не звона и прапории, Београд: Да се зна!

Kulpa, R. (2014). "Western leveraged pedagogy of Central and Eastern Europe: discourses of homophobia, tolerance, and nationhood", Gender, Place \& Culture: A Journal of Feminist Geography 21(4): 431-448.

Маљковић, Д. (2014). „То ради у теорији, али не у пракси’ - Идентитетски (ЛГБТ) активизам против квир активизма“" (“"That Works in Theory, but Not in Practice: Identity (LGBT) Activism Against Queer Activism"'), y: J. Благојевић и О. Димитријевић (ур.) Међу нама: Неиспричане приче геј и лезбејских живота (Between Us: Untold Stories of Gay and Lesbian Lives), Београд: Heartefact, стр. 361-369.

Mendelski, M. (2016). "Europeanization and the Rule of Law: Towards a Pathological Turn", Southeastern Europe 40(3): 346-384. DOI 10.1163/18763332-04003003

Mikuš, M. (2011). “'State Pride' Politics of LGBT Rights and Democratisation in 'European Serbia"”, East European Politics and Societies 25(4): 834-851. DOI 10.1177/0888325411426886

Mikuš, M. (2015). “'Faggots Won’t Walk through the City': Religious Nationalism and LGBT Pride Parades in Serbia”, in: S. Sremac \& R. R. Ganzevoort (eds.) Religious ans Sexual Nationalisms in Central and Eastern Europe: Gods, Gays and Governments, Leiden: Brill, pp. 15-32. DOI 10.1163/9789004297791_003

Mungiu-Pippidi, A. (2014). "The Transformative Power of Europe Revisited", Journal of Democracy 25(1): 20-32. DOI 10.1353/jod.2014.0003

Николић, О. (2012). „Забрана дискриминације ЛГБТ популације и слобода окупљања и удруживања" ("Prohibition of Discrimination of LGBT Population and Freedom of Assembly and Association"), у: А. Рабреновић и J. Ћеранић (ур.) Усклађивање права Републике Србије са правним тековинама ЕУ: приоритети, проблеми, перспективе, Београд: Институт за упоредно право, стр. 139-151.

Pešić, V. (2007). State Capture and Widespread Corruption in Serbia. CEPS Working Document No. 262/March 2007. Доступно на интернет адреси: https://www.ceps.eu/publications/state-capture-and-widespread-corruptionserbia (последња посета: 2. 3. 2018)

Radaelli, C. M. (2004). “Europeanisation: Solution or Problem?”, European Integration online Papers (EIoP) 8 (16): 1-26. Доступно на интернет адреси: https://ssrn. com/abstract=601163 (последња посета: 1.2 .2018 )

Радоман, М. (2017). „Бити LGBTTIQ - значења која нас обликују”, Култура: часопис за тероију и социологију културе и културну политику (157), стр. 203-219. DOI: 10.5937/kultura1757203R

Rettman, A. (2012). "Gay rights is EU entry criterion, Brussels says", EU Observer July 13 2012. Доступно на интернет адреси: https://euobserver.com/lgbti/ 116963 (последња посета: 3. 3. 2018)

Schimmelfennig, F. \& Sedelmeier, U. (2005). "Introduction: Conceptualizing the Europeanization of Central and Eastern Europe”, in: F. Schimmelfennig \& U. Sedelmeier (eds.) The Europeanization of Central and Eastern Europe, Ithaca, NY: Cornell University Press, pp. 1-28.

Slootmaeckers, K. (2017a). "The litmus test of pride: analysing the emergence of the Belgrade 'Ghost' pride in the context of EU accession", East European Politics 33(4), 517-535. DOI: 10.1080/21599165.2017.1367290

Slootmaeckers, K. (2017b). "Serbia's New Lesbian Prime Minister: A Symbolic Step Forward?", Balkanist June 17, 2017. Доступно на интернет адреси: http://balkanist.net/serbia-new-prime-minister/ (последња посета: 3. 3. 2018) 
Stakić, I. (2011). "Homophobia and Hate Speech in Serbian Public Discourse: How Nationalist Myths and Stereotypes Influence Prejudices against the LGBT Minority", The Equal Rights Review 7: 44-65.

Стојаковић, А. (ур.) (2014). Парада поноса и ЛГБТ популаиија (Pride Parade and LGBT Population), Београд: Центар за квир студије.

Stojanović, J. (2013). "EU political conditionality towards Serbia: membership prospects vs. domestic constraints", in: A. Elbasani (ed.) European Integration and Transformation in the Western Balkans: Europeanization or business as usual?, London; New York: Routledge, pp. 54-69.

Subotić, J. (2010). "Explaining Difficult States: The Problems of Europeanization in Serbia”, East European Politics and Societies 24(4): 595-616. DOI 10.1177/ 0888325410368847

Subotić, J. (2017). "Building Democracy in Serbia: One Step Forward, Three Steps Back", in: S. P. Ramet, C. M. Hassenstab \& O. Listhaug (eds.) Building Democracy in the Yugoslav Successor States: Accomplishments, Setbacks, and Challenges since 1990, Cambridge: Cambridge University Press, pp. 165-191. DOI: $10.1017 / 9781316848289.008$

Swimelar, S. (2017). "The Journey of LGBT Rights: Norm Diffusion and its Challenges in EU Seeking States: Bosnia and Serbia”, Human Rights Quarterly 39(4): 910-942. DOI: 10.1353/hrq.2017.0054

Зекавица, Р. (2016). „Друштвени и правни статус ЛГБТ особа с посебним освртом на случај Србије" (“Social and Legal Status of LGBT People - With Special Reference to the Case of Serbia"), у: В. Бораниашијевић (прир.) Правни систем и заштита од дискриминачије - зборник радова. Друга свеска (Legal System and Protection Against Discrimination - Proceedings, The Second Volume), Косовска Митровица: Правни факултет Универзитета у Приштини са привременим седиштем у Косовској Митровици, стр. 343-359.

\title{
LGBT PERSONS IN SERBIA: BETWEEN FORMAL ACCEPTANCE AND INFORMAL REJECTION
}

\author{
Miloš Jovanović \\ University of Niš, Faculty of Philosophy, Department of Sociology, Niš, Serbia
}

\section{Summary}

Generally speaking, Europeanization is defined as "a process in which states adopt EU rules". As Serbia is getting closer to the EU, this process is gaining on its momentum, but running far from smoothly. Formal endeavors aimed at the change of the social status of the LGBT persons in Serbia are a case in point, as they are linked to the idea of Europeanization. In accordance with the EU conditions - as a political precondition for joining the Union, it is stated that the candidate country must have "stable institutions which guarantee democracy, the rule of law, and respect and protection of minority rights," and one of the segments of this requirement that emerges is the relation of the state towards sexual minorities - a series of measures have been taken with the aim of improving the social position of LGBT persons: a series of laws were passed which contained provisions focused on fighting discrimination against nonheterosexual persons, programs were realized and action plans made with the same goal in mind, and also several Pride Parades took place without major incidents (as Belgrade 
was "besieged" by heavy police forces), with LGBT affirming events taking place in other cities (Novi Sad, Niš) besides the capital. All of the mentioned measures and events had an impact on the changes in the attitudes of the citizens of Serbia towards homosexuals, but these attitudes still remain predominantly marked by intolerance and judgment

The hypothesis of the paper is that in the case of the stand that Serbia takes in relation to the LGBT population there is something that reveals the paradigm for the more general process of Europeanization of this country: the formal obligations are being fulfilled, but no major effort is being invested in bringing about more significant social changes - the adopting rules which do not reach a "substantial level" (Elbasani). Activities represented as positively oriented towards LGBT persons are short-term and superficial. The challenges and resistance of the government bodies and officials are not to be found on the level of official discourse, but instead on the level of practice, so the formal endeavors remain "empty shells" with little or no actual social influence at all, as the high state officials publicly manifest their reluctance toward non-heterosexuals, the police practices indirect resistance toward organizing the Pride, the appropriate application of the laws in practice is lacking, and the absence of any adequate application, and the ineffectiveness of the judiciary when it comes to attacks on LGBT persons creates a public space which is characterized by a culture of impunity.

The Serbian political elite, through "tactical Europeanization" - "an act of compliance to communicate to the EU a readiness to Europeanize by aligning oneself with certain 'European norms"' (Slootmaeckers), carries out the appropriation and exploitation of the Parade ("State Pride", Mikuš) and thus demonstrates its (alleged) orientation towards Europe, without any real interest in LGBT issues, which is confirmed by the homophobic statements made by leading politicians, which are also a form of cowtowing to their conservative electoral base.

All of the activities which explicitly focus on the emancipation and proper treatment of non-heterosexuals, have as their (non-intended) consequences the masking of their actual status, and are reduced to spectacles and empty promises. The strategies of the EU which are supposed to turn discrimination into tolerance and acceptance are not enough. Attempts to implement EU rules and regulations seem to be of no avail if local adaptation, interpretation and appropriation of these norms and the resistance which they spawn, is not taken into account. 